\title{
A gyógyszerfüggőség előfordulásának vizsgálata pszichiátriai és addiktológiai rehabilitációs osztályokon kezelt betegek között
}

\author{
Tóth Viktória dr. ${ }^{1}$ - Molnár Beáta dr. ${ }^{2}$ - Gazdag Gábor dr. ${ }^{2,3}$ \\ ${ }^{1}$ Achillea Gyógyszertár, Budapest \\ ${ }^{2}$ Jahn Ferenc Dél-pesti Kórház és Rendelőintézet, Pszichiátriai és Addiktológiai Centrum, Budapest \\ ${ }^{3}$ Semmelweis Egyetem, Általános Orvostudományi Kar, Pszichiátriai és Pszichoterápiás Klinika, Budapest
}

Bevezetés: A nyugtatószer-függőség az egész világban, így Magyarországon is egyre aggasztóbb méreteket ölt. Az egyéb függőségben is szenvedők, valamint a pszichiátriai betegek különösen veszélyeztetettek a gyógyszerfüggőség szempontjából. A probléma valós nagyságáról azonban kevés tudományos adattal rendelkezünk.

Célkitüzés: Benzodiazepin hatóanyagú gyógyszerek használatának vizsgálata egy budapesti kórház pszichiátriai rehabilitációs és addiktológiai rehabilitációs osztályán kezelt betegei fogyasztási szokásainak felmérésével és összehasonlításával.

Módszer: A vizsgálat alapjául a két osztály 103 betege által anonim módon, önkéntesen, interjú során kitöltött, a nyugtatószer-használati szokásokra, illetve az ezzel kapcsolatos viselkedésekre vonatkozó, 19 kérdésből álló kérdőív szolgált.

Statisztikai analízis: A demográfiai adatok leírása az átlaggal és a szórással vagy százalékos arányok megadásával történt. A csoportok összehasonlítására a minta eloszlásának megfelelően t-próbát, Mann-Whitney-féle U-tesztet vagy khi-négyzet-próbát alkalmaztunk.

Eredmények: A gyógyszerfüggőségre utaló tünetek, a többféle nyugtató együttes használata, valamint a nyugtatószedés alkoholfogyasztással történő kombinálása is nagyon gyakori volt mindkét osztály betegei között. Az eredmények ugyanakkor számos kérdésnél szignifikáns különbséget mutattak a két mintában. A gyógyszerabúzus szignifikánsan gyakrabban fordult elő az addiktológiai betegek között, valamint az illegális csatornákon történő gyógyszerbeszerzés is ehhez a betegcsoporthoz köthető. A szociális státuszra vonatkozó demográfiai jellemzők, közülük is kiemelkedő módon a lakhatás, jelentősen befolyásolja a nem orvosi rendelésre történő gyógyszerfogyasztást.

Következtetések: Az eredmények a gyógyszerfüggőség gyakoriságára hívják fel a figyelmet az addiktológiai és pszichiátriai betegek között, jelezve, hogy sürgős lépések szükségesek a probléma visszaszorítása érdekében.

Orv Hetil. 2020; 161(15): 594-600.

Kulcsszavak: nyugtatószer, függőség, illegális anyagok, pszichiátria, addiktológia

\section{Survey of anxiolytic drug dependence in patients treated in psychiatric and addiction rehabilitation wards}

Introduction: Anxiolytic drug dependence is a cause for growing concern worldwide including Hungary. Psychiatric patients and patients with other drug addictions are at increased risk for anxiolytic drug dependence. Yet, there is only limited scientific information about the real extent of this issue.

Aim: To examine the frequency of use of benzodiazepine-containing drugs and comparing the consumption habits of patients treated in psychiatric and addiction rehabilitation wards in a hospital in Budapest.

Method: The survey was based on an anonymously and voluntarily completed questionnaire during a face-to-face interview of 103 patients in two wards. The 19-item questionnaire targeted anxiolytic drug use and related behavioral patterns.

Statistical analysis: Socio-demographic data were given with means and standard deviations or with percentages as appropriate. For the comparison between the two groups of patients, t-test, Mann-Whitney U-test or chi-square test were used in accordance with the distribution of the sample. 
Results: Symptoms indicating anxiolytic dependence, use of multiple anxiolytics, and combination of anxiolytic drugs with alcohol were very frequent in both wards. However, there were some significant differences between the two samples. Anxiolytic drug abuse and illicit drug use were significantly more frequent in patients at the addiction ward. Indicators of social status, particularly the place of residence, significantly influenced non-prescription misuse of anxiolytic drugs.

Conclusions: The results draw attention to the high frequency of anxiolytic drug misuse and dependence in psychiatric and addiction patients warranting urgent action to confront this challenge.

Keywords: anxiolytics, dependence, illicit substances, psychiatry, addiction medicine

Tóth V, Molnár B, Gazdag G. [Survey of anxiolytic drug dependence in patients treated in psychiatric and addiction rehabilitation wards]. Orv Hetil. 2020; 161(15): 594-600.

(Beérkezett: 2020. január 3.; elfogadva: 2020. február 1.)

\section{Rövidítések}

BZD = benzodiazepin; DDD = (defined daily dose $)$ napi terápiás dózis; ESPAD $=($ European School Survey Project on Alcohol and Other Drugs) Európai Alkohol- és Kábítószerhasználati Iskolai Felmérő Program; NEAK = Nemzeti Egészségbiztosítási Alapkezelő (az OEP jogutódja); OGYI = Országos Gyógyszerészeti Intézet

A természetben előforduló nyugtató hatású szereket évezredek óta használja az emberiség. A modern gyógyszerek megjelenése előtt elterjedt, a központi idegrendszert befolyásoló feszültségoldó szer a morfin és az alkohol volt. Az 1800-as években altatóként jelentek meg a szervetlen bromid sók, mérgező hatásuk miatt azonban alkalmazásuk háttérbe szorult. Az 1900-as évektőll a barbitursav-származékok számítottak a legelterjedtebb szedatohipnotikumoknak. A barbiturátok közel két évtizedes növekvő népszerüsége után kiderült, hogy mellékhatásaik veszélyesek, tolerancia és dependencia is kialakul használatuk során. Szúk a terápiás indexük, szorongáscsökkentő és antiepileptikus hatást előidéző dózisuk közel van a légzésdepressziót okozó dózishoz, így használatuk visszaszorult, helyüket fokozatosan a benzodiazepinek vették át [1].

A gyógyszerfüggőség előfordulási gyakoriságát megbecsülni is nehéz. Hazánkban a felnőtt populációt érintó vizsgálatok száma kevés, a fiatalok érintettségéról az Európában 4 évente megjelenő ESPAD-jelentésekból kaphatunk képet [2]. E szerint az orvosi rendelvény nélkül használt nyugtatók és altatók élettartam-prevalenciája Magyarországon 20 évre visszamenőleg az európai uniós átlag felett van. A kétezres évek elején tapasztalható magas értékek 2015-re 30\%-os csökkenést mutattak [2].

Egy 2011-ben publikált magyarországi vizsgálat szerint a magyar nők kétszer gyakrabban (41,9\%) fogyasztanak életük során nyugtató vagy altató hatású szereket, mint a férfiak $(22,7 \%)$. Az orvosi rendelvény nélkül szedett nyugtatók élettartamprevalencia-adataiban hasonló arány mutatkozott: nők esetében $4,3 \%$, férfiak esetében $2,4 \%$ volt. Az egyes korosztályok érintettségében is kü- lönbségek mutatkoztak: a legkevesebben a 35-44 évesek $(1,7 \%)$, a legtöbben a $45-54$ évesek $(5,3 \%)$ használtak recept nélkül altatót és nyugtatót. A rendelvény nélküli nyugtató és alkohol együttes használatának havi prevalenciaértéke $4 \%$ volt a vizsgálatban [3].

Nyilvános gyógyszerfogyasztási adatokból is következtethetünk a nyugtatószedés mértékére. A NEAK adatai alapján az alprazolám és a klonazepám 2017. évi teljes elfogyasztott mennyisége megfelel annak, mint ha a népesség 3,9\%-a szedett volna 2017-ben az év minden napján terápiás dózisnak (DDD) megfelelő mennyiséget ezekből a hatóanyagokból. Az alprazolám esetén ez körülbelül 260 ezer fốt jelent, a klonazepámnál pedig közel 122 ezer embert (1. ábra). Ezekboól az adatokból nem lehet ugyan meghatározni a gyógyszerrel kapcsolatos visszaélések számát, de az látszik, hogy a fent említett hatóanyagoknak a rendszeres, napi fogyasztása az össznépesség minimum 3,9\%-át érinti [4].

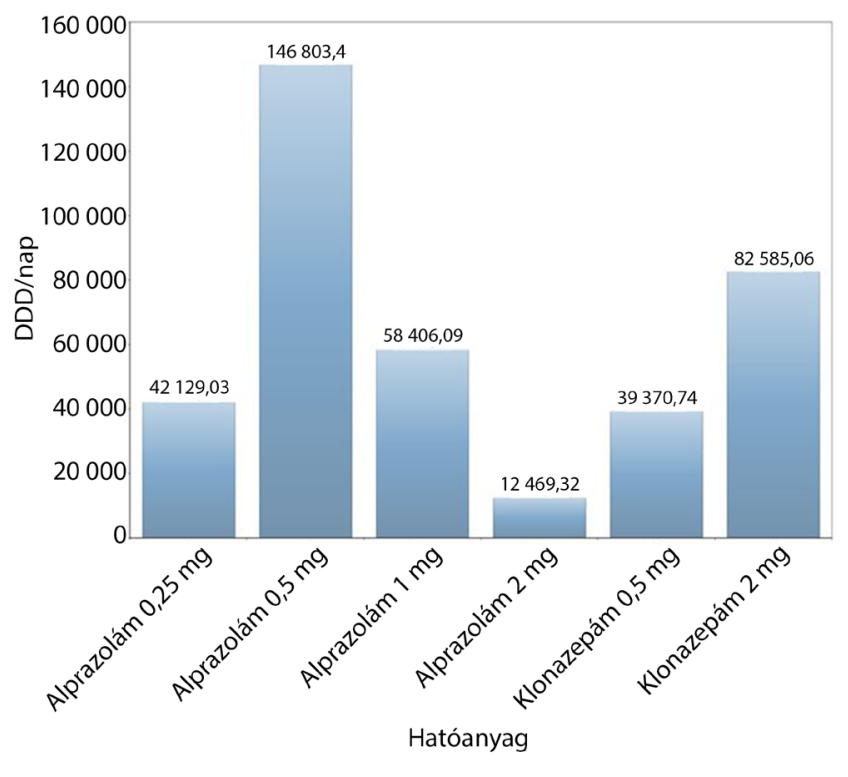

1. ábra $\quad$ A 2017. évi gyógyszerfogyasztási adatok Magyarországon a Nemzeti Egészségbiztosítási Alapkezelő gyógyszerforgalmi adatai alapján 


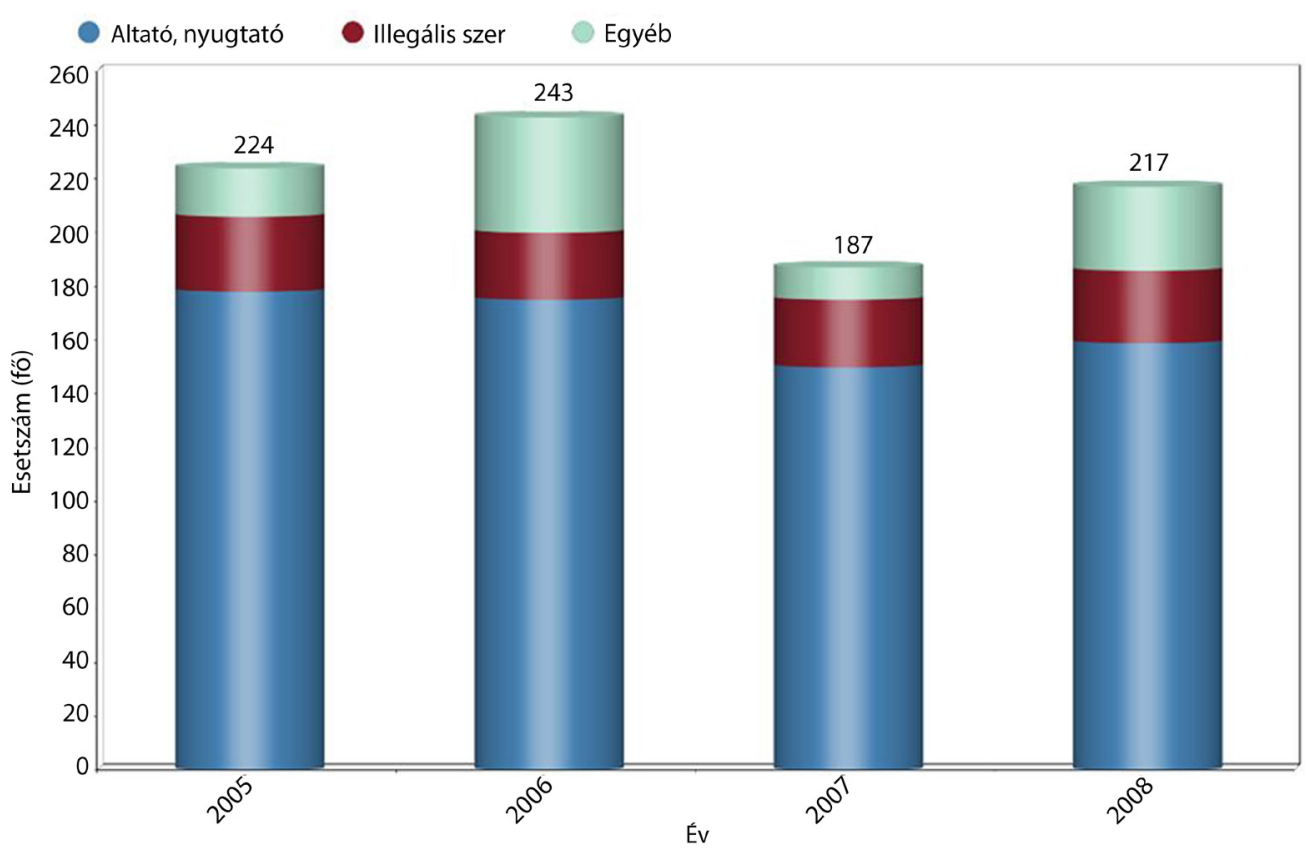

A mérgezés okozta halálozások száma is támpontot adhat a probléma súlyosságára vonatkozóan. A nyugtató- és altatószer-mérgezés kapcsán előfordult direkt halálesetekrôl csak 2005-tól 2008-ig tesznek említést a magyarországi kábítószerhelyzetről készült éves jelentések [5]. Az összes haláleset bekövetkezésében legális és illegális szerek is szerepet játszanak, de legnagyobb részükért az altatókkal és nyugtatókkal való visszaélés felelős (2. ábra).

Ugyanakkor gyógyszerfüggőség miatti kezelési igény csak minimális arányban jelenik meg. 2015-ben 79, függőséggel foglalkozó kezelési egység jelentése alapján a teljes kezelési igény 3,6\%-a volt köthetô az elsődlegesen nyugtatót és altatót fogyasztókhoz [5].

\section{Célkitüzés}

A vizsgálat célja az altatók és nyugtatók használati szokásainak felmérése és összehasonlítása egy budapesti kórház pszichiátriai rehabilitációs és addiktológiai rehabilitációs osztályán kezelt betegei között.

\section{Módszer}

A vizsgálat a Jahn Ferenc Dél-pesti Kórház és Rendelőintézetben, az I. és a III. Pszichiátriai Rehabilitációs Osztályon és a Pszichiátriai Addiktológiai Rehabilitációs Osztályon történt 2018 januárjában. A pszichiátriai rehabilitációs osztályok általános pszichiátriai rehabilitációs profillal múködnek, nagyrészt az Akut Pszichiátriai Osztályról további rehabilitációra szoruló betegeket látják el, de III. progresszivitási szintű osztályokként Budapest más akut pszichiátriai osztályairól is vesznek át betegeket ellátásra. A Pszichiátriai Addiktológiai Rehabilitá- ciós Osztály ugyancsak III. progresszivitási szinten föként Budapest dél-pesti régiójából, de 1-l esetben az ország távolabbi pontjairól is fogad betegeket. A vizsgálat anonim módon zajlott, a válaszadás önkéntes alapon történt, a felvett kérdőív semmilyen azonosításra alkalmas adatot nem tartalmazott. A kutatás a Jahn Ferenc Dél-pesti Kórház és Rendelőintézet Intézeti Kutatásetikai Bizottságának engedélyével folyt. A bevont személyek a vizsgálatban való részvételhez tájékoztatást követően írásbeli beleegyezésüket adták.

A vizsgálatba minden olyan beteg bevonásra került, aki 2018. január l. és január 31. között az I. vagy a III. Pszichiátriai Rehabilitációs Osztályon vagy a Pszichiátriai Addiktológiai Rehabilitációs Osztályon állt kezelés alatt, aki a kérdő́ív kitöltésére alkalmas szomatikus, illetve kognitív állapotban volt, akinél nem volt nyelvi akadálya a kérdőív kitöltésének, és aki vállalta a vizsgálatban való részvételt.

$\mathrm{Az}$ adatgyújtésre személyes interjú során került sor (az interjúkat T. V. végezte), a kérdéssor 16 kérdésből állt. Az első 6 kérdés a demográfiai adatokra kérdezett rá. A további 12 kérdés a gyógyszerek használatára vonatkozott, amiből 3 esetén kínáltunk több választási alternatívát, a maradék 8 egyszerú eldöntendő kérdés volt (Melléklet).

\section{Statisztikai módszerek}

A demográfiai adatok leírása az átlaggal és a szórással vagy százalék megadásával történt. A csoportok összehasonlítására a folyamatos változó normáleloszlása esetén t-próbát, a normáltól eltérő eloszlás esetén Mann-Whitney-féle U-tesztet, diszkrét változók esetén khi-négyzetpróbát alkalmaztunk. Szignifikanciaszintnek a p $<0,05$-ot választottuk. 


\section{Eredmények}

A vizsgálatban való részvételre 168 beteg került felkérésre: 80 pszichiátriai rehabilitációban, 88 addiktológiai rehabilitációban részesülő beteg. A kérdőívet végül összesen 103 fó töltötte ki (51 pszichiátriai rehabilitációban, 52 addiktológiai rehabilitációban részesült), a válaszadók $52 \%$-a volt férfi. A legfiatalabb válaszadó 22 , a legidősebb 88 éves volt, átlagéletkoruk $53,3 \pm 2,4$ év volt. A pszichiátriai és az addiktológiai rehabilitációs osztályról a vizsgálatban részt vevő betegek kor és nemek szerinti eloszlásában nem volt szignifikáns különbség. A két csoport demográfiai jellemzőit az 1. táblázat mutatja.

A két csoport összehasonlítása során számos jellemzőben szignifikáns különbség mutatkozott. A gyógyszerszedés időtartamát tekintve a pszichiátriai rehabilitációs osztályon fekvők 56,8\%-a egyáltalán nem vagy 5 évnél kevesebb ideje szedett nyugtatókat, az addiktológiai rehabilitációs osztályon viszont 5 évnél régebb óta alkalmazta a megkérdezettek $63,5 \%$-a $(\mathrm{p}=0,027)$. A toleranciával kapcsolatos válaszokban megjelenő, tendenciaszerü különbség ( $\mathrm{p}=0,054)$ is az addiktológiai betegek súlyosabb problémáját jelzi. A gyógyszerszedés időtartama a nemek esetén is lényegesen különbözött, a férfiak $61,1 \%$-a szedte 5 évnél rövidebb ideje a vizsgált gyógyszereket, miközben a nók esetén az 5 évnél régebb óta gyógyszert szedők aránya $69,4 \%$ volt $(\mathrm{p}=0,005)$.

A felsőfokú iskolát végzettek közel 50\%-a érezte már korábban, hogy többet kell nyugtatóból bevennie, hogy hasson. Ez az arány jóval magasabb volt a csak 8 osztályt

1. táblázat |A vizsgálatban részt vevő addiktológiai és pszichiátriai betegek demográfiai adatainak összehasonlítása

\begin{tabular}{|c|c|c|c|}
\hline & Addiktológia & Pszichiátria & Statisztika \\
\hline Életkor (év) & $51,6 \pm 12,2$ & $55,1 \pm 16,6$ & $\mathrm{p}=0,22$ \\
\hline Nem & & & $\mathrm{p}=0,77$ \\
\hline férfi & 28 & 26 & \\
\hline nő & 24 & 25 & \\
\hline Iskolai végzettség & & & $\mathrm{p}=0,60$ \\
\hline 8 általános & 10 & 14 & \\
\hline szakmunkás & 21 & 15 & \\
\hline érettségi & 10 & 12 & \\
\hline felsőfokú & 11 & 12 & \\
\hline Családi állapot & & & $\mathrm{p}=0,29$ \\
\hline házas/kapcsolatban & 14 & 19 & \\
\hline elvált/özvegy & 18 & 11 & \\
\hline egyedülálló & 20 & 21 & \\
\hline Munkaügyi státusz & & & $\mathrm{p}=0,21$ \\
\hline tanuló & 0 & 1 & \\
\hline dolgozó & 15 & 12 & \\
\hline leszázalékolt & 15 & 7 & \\
\hline munkanélküli & 10 & 13 & \\
\hline nyugdíjas & 12 & 18 & \\
\hline Lakhatás & & & $\mathrm{p}=0,09$ \\
\hline saját lakás & 28 & 38 & \\
\hline albérlet & 14 & 7 & \\
\hline hajléktalan & 10 & 6 & \\
\hline
\end{tabular}

\section{Melléklet}

\section{Nyugtatószer-használatra vonatkozó kérdőív}

Monogram:

Életkor:

Nem:

Iskolai végzettség: $\square 8$ általános $\square$ szakmunkásiskola

Családi állapot:

\section{$\square$ érettségi $\square$ felsőfokú}

$\square$ házas/párkapcsolatban

$\square$ elvált/özvegy $\square$ egyedülálló

Lakhatás:

$\square$ saját lakás $\square$ albérlet

$\square$ hajléktalan

Munkaügyi státusz: $\square$ tanuló $\square$ dolgozó

$\square$ munkanélküli $\quad \square$ leszázalékolt

$\square$ nyugdíjas

Az alábbi egyszerü kérdőivvel az Ön nyugtatószer-használati szokásait szeretnénk felmérni.

Kérjük, hogy jelölje X-szel az Önre érvényes választ!

1) Az alábbi gyógyszerek közül szedte-e valamelyiket korábban?

$\square$ Frontin $\square$ Seduxen $\square$ Rivotril

$\square$ Xanax $\square$ egyéb altató

2) Milyen régóta szedi a fent említett gyógyszereket? $\square \mathrm{l}$ évnél rövidebb $\square$ 1-5 év $\square$ 5-10 év $\square 10$ évnél régebb óta

3) Érzett-e olyat, hogy ahhoz, hogy a gyógyszer hasson, többet kell bevennie belőle, mint korábban? $\square$ igen

$\square$ nem

4) Ismeri-e a fent említett gyógyszerek mellékhatásait? $\square$ igen

$\square$ nem

5) Előfordult, hogy az orvos által elooírt nyugtatóin felül további nyugtatót vett be?

$\square$ igen $\quad \square$ nem

6) Előfordult, hogy egyszerre többféle nyugtatót vett be?

$\square$ igen

$\square$ nem

7) Fogyaszt alkoholt a nyugtató mellé? Előfordult, hogy a nyugtatót alkohollal vette be?

$\square$ igen $\quad \square$ nem

8) Előfordult olyan eset, hogy testi elvonási tünetek (pl. remegés, gyengeség, szédülés stb.) jelentkeztek, amikor abbahagyta a nyugtatószer szedését, vagy csökkentette az adagot?

$\square$ igen

$\square$ nem

9) Észlelte már az alábbi tüneteket nyugtatószedés következtében?

$\square$ memóriazavar $\square$ gyengeség $\square$ fáradékonyság $\square$ remegés

10) Próbálta már befejezni a nyugtatószedést? $\square$ igen $\square$ nem

11) Kezelték-e már kórházban nyugtatószedéshez kapcsolódóan?

$\square$ igen

$\square$ nem

12) Próbált már illegális úton (piac, internet stb.) gyógyszerhez jutni?

$\square$ igen

$\square$ nem 
végzettek $(81,8 \%)$ és az érettségizettek esetén $(75 \%)(\mathrm{p}=$ 0,032 ).

A nyugtatók mellékhatásait a pszichiátriai rehabilitációs osztály betegei közül csak 32,6\% ismerte, ami szignifikánsan alacsonyabb volt az addiktológián talált 44,2\%nál $(\mathrm{p}=0,034)$. Általánosságban megállapítható, hogy a megkérdezettek mindössze 37,8\%-a ismerte a nyugtatók, altatók mellékhatásait, amit a demográfiai jellemzók nem befolyásoltak.

A gyógyszerek orvosi eloóráson felüli használatára a megkérdezettek fele igennel válaszolt, az addiktológiai profilú osztály betegei közül $69,3 \%$, a pszichiátriai rehabilitációs osztályon pedig 30,7\% ( $\mathrm{p}<0,001)$. A hajléktalanok $80 \%$-a nem az orvosi rendelvénynek megfelelóen szedte a nyugtatókat, míg a saját lakással vagy albérlettel rendelkezők esetén ez lényegesen kevesebbszer, csak az esetek 37,5\%-ában fordult elő $(p=0,005)$. A nyugdíjasok $75,9 \%$-a soha nem próbált meg több gyógyszert bevenni, mint amennyit a szakember előírt, ezt a javaslatot a dolgozók közül csak 32\% tartotta be.

Az abúzusra vonatkozó kérdések tekintetében is szignifikáns eltérés mutatkozott a két osztály között. Többféle nyugtatót együttesen alkalmazott a pszichiátriai rehabilitációs betegek közül 26,1\%, míg az addiktológiai osztályon kezelt betegek 38,4\%-a $(\mathrm{p}=0,029)$.

Jelentős eltérés volt megfigyelhető a gyógyszerek és alkohol együttes alkalmazásában, aminek elófordulása az addiktológiai páciensek 55,7\%-ára, a pszichiátriai rehabilitációs osztályon kezelt betegeknek pedig a 17,4\%-ára volt igaz $(\mathrm{p}<0,001)$. A lakhatás is szignifikánsan befolyásolja az alkohollal történő visszaélés előfordulását. A saját lakással rendelkező́knek csak a 21,8\%-a, a hajléktalanok 57,1\%-a, míg az albérletben élők 75\%-a ivott már alkoholt gyógyszerfogyasztás mellett $(\mathrm{p}<0,0001)$. További jelentős különbség figyelhetô meg ebben a kérdésben a munkaügyi státuszt illetően: a dolgozók, munkanélküliek, leszázalékoltak közel fele válaszolt igennel, míg a nyugdíjasok közül csak $10 \%(\mathrm{p}=0,016)$.

Elvonási tüneteket az addiktológiai osztályon jelentősen többen észleltek $(69,2 \%)$, mint a pszichiátriai rehabilitációs részlegen $(58,7 \%)(\mathrm{p}=0,038)$.

Mellékhatást a gyógyszerszedés következtében a betegek 37,8\%-a egyáltalán nem észlelt. Akik észleltek, azok a leggyakrabban memóriazavarra $(11,2 \%)$ és fáradtságra $(15,3 \%)$ panaszkodtak.

$\mathrm{Az}$ addiktológiai betegek 75\%-a tett kísérletet a rendszeres gyógyszerszedésrő́l való leszokásra, míg a pszichiátriai rehabilitációs osztályon ez az arány $60,9 \%$ volt $(\mathrm{p}=$ $0,022)$. A gyógyszerabúzus miatti kórházi kezelések előfordulásában is szignifikáns különbséget találtunk: az addiktológiai osztályon ez az arány $50 \%$-nak, a pszichiátriai rehabilitáción lévők között 39,1\%-nak adódott ( $\mathrm{p}=$ 0,038). A felsőfokú végzettséggel rendelkezők közül csak 19\%-nak, ezzel szemben az érettségizettek közül szignifikánsan több embernek, 70\%-nak volt szüksége kórházi kezelésre a gyógyszerszedése miatt $(\mathrm{p}=0,02 \mathrm{l})$. A családi állapot is jelentősen befolyásolta a BZD-k miat- ti kezelési igényt. Az egyedülállók 64\%-ának volt már szüksége kezelésre, míg ez az arány a párkapcsolatban élók és az elváltak esetén csak 32\%-nak adódott ( $\mathrm{p}=$ $0,042)$.

Az addiktológiai osztályon kezelt betegek 15,4\%-a próbált már illegális úton gyógyszerhez jutni, míg ez az arány a pszichiátriai rehabilitációs osztályon mindössze $4,3 \%$ volt $(\mathrm{p}=0,014)$. A páciensek $89,8 \%$-a soha nem próbált még illegális forrásból nyugtatóhoz jutni, azonban szignifikáns különbségeket mértünk abban, hogy míg a saját lakással rendelkező́knek csak a 3,1\%-a próbált illegális úton gyógyszerhez jutni, az albérletben lakók közül ezt 30\%, a hajléktalanok közül 14,3\% kísérelte meg $(\mathrm{p}=0,005)$

\section{Megbeszélés}

Az addiktológiai és a pszichiátriai rehabilitációs osztályok összehasonlításában csak két esetben nem találtunk szignifikáns különbséget a válaszok között. Az egyik kérdés a tolerancia kialakulására, a másik pedig a mellékhatások észlelésére vonatkozott.

Az addiktológiai osztályon többen ismerik a gyógyszerek mellékhatásait, és régebb óta szedik őket, mint a pszichiátriai rehabilitációs osztályon. A gyógyszerabúzusnak minősülő magatartások (6., 7. és 8. kérdés) egyértelmúen többször fordultak elő az addiktológiai osztályon. A nyugtatók nem megfeleló használata miatti kórházi kezelésre az addiktológiai osztályon kezelt betegek felének volt már szüksége, de a pszichiátriai rehabilitációs osztály betegei közül is közel $40 \%$-nak volt már emiatt ellátása, ami magas aránynak tekinthető, figyelembe véve, hogy nem függőségi problémákkal foglalkozó osztály betegeiról van szó. Az alkohol és gyógyszer együttes fogyasztása az addiktológiai osztály betegeinek esetén több mint háromszor gyakrabban fordult már elő, ami megerősíti azt a feltételezést, hogy a szenvedélybetegségekkel küzdő páciensek függősége nemcsak egy szerhez köthető, hanem több pszichoaktív szer együttes abúzusa is előfordul. Az alkohol és a nyugtatók együttes használatának magas előfordulási aránya figyelemfelhívó kell, hogy legyen a nyugtatót rendelő orvosok számára. Az illegális úton való gyógyszerbeszerzés egy tipikus tünete a függőségnek. A teljes mintát tekintve kevesen szerezték be ugyan a gyógyszereket ilyen úton, ugyanakkor a beszerzés ilyen módja $80 \%$-ban az addiktológiai páciensekhez volt köthető.

Több korábbi kutatás $[6,7]$ azt igazolta, hogy a nők gyakrabban használnak visszaélés-szerúen nyugtatókat, ugyanakkor a jelen vizsgálatban csak a használati időtartam tekintetében mutatkozott szignifikáns különbség a nemek között, a gyakoriságban nem. Ennek az lehet a magyarázata, hogy a vizsgálat nem reprezentatív mintán történt, hanem klinikai szempontból súlyosabb, kórházi kezelésre szoruló beteganyagon.

A demográfiai jellemzók is jelentős összefüggést mutatnak a gyógyszerszedési szokásokkal a vizsgálat szerint. 
A demográfiai jellemzők közül az eredmények alapján a lakhatás befolyásolja a leginkább a gyógyszerszedési szokásokat. Az albérletben élők közül kiugróan magas azok száma, akik már az előírt dózison felül vagy alkohollal együtt fogyasztottak nyugtatókat és altatókat, valamint próbáltak már illegális forrásból is gyógyszert szerezni. Ezek a viselkedésminták a bizonytalan életkörülményekből fakadó stresszre adott válaszként értelmezhetők.

Az egyedülállók közel kétharmadát kezelték már kórházban nyugtatószedéshez kapcsolódóan, amit a környezeti kontroll hiánya, valamint a társas kapcsolatok lazább volta magyarázhat.

A nyugdíjasok között - a más munkaügyi státuszú csoportokkal szemben - a legtöbben betartják az orvos nyugtatószedésre vonatkozó elóírásait, és nem kombinálják azt alkohollal, ami talán a nyugodtabb életformának és az orvossal való gyakoribb találkozásnak, szorosabb személyes kapcsolatnak köszönhető. A jelenleg is dolgozók, munkanélküliek, leszázalékoltak több mint fele vett már be több nyugtatót az elöírtnál. A dolgozóknál a munkahelyi stressz, a leszázalékoltak és a munkanélküliek körében pedig az egzisztenciájuk miatti aggódás magyarázhatja ezt a viselkedést. A munkahellyel rendelkezők voltak továbbá azok, akik a legtöbben használták már együtt alkohollal a nyugtatókat és az altatókat.

A legtöbb kérdésre adott választ az iskolai végzettség nem befolyásolta, de a tolerancia kialakulásának valószínúsége, valamint a kórházi kezelések előfordulása a felsőfokú végzettséggel rendelkezők esetén mégis jóval kisebb volt, mint az alacsonyabb végzettségưek között, miközben a további gyógyszerszedési szokások tekintetében nem mutatkoztak jelentős különbségek. Ez feltételezésünk szerint a felsőfokú végzettségűek egészségügyi kérdésekben mutatkozó nagyobb tájékozottságával, egészségtudatosságával lehet összefüggésben.

\section{Nemzeti stratégia a probléma kezelésére}

A Nemzeti Drogellenes Stratégia vállalása, hogy 2013 és 2020 között az alkohol gyógyszerrel történő alkalmazását - életprevalencia-értéke 10,3\% - csökkenti 2\%-kal, valamint a nyugtatók és altatók orvosi rendelvény nélküli alkalmazását a fiatalkorúak körében - életprevalenciaértéke $9,3 \%$ - is tovább redukálja. A tervezet további célkitûzései között szerepel, hogy csökkentse az orvosi rendelvényre szabályosan kiváltott gyógyszerek visszaélésszerü használatát, valamint a legális gyógyszerellátási csatornákon keresztül forgalmazott szerek mennyiségét [8].

A későbbi szerhasználat megelőzésének leghatékonyabb módszere a primer prevenció, melynek elsődleges színtere az iskola. A szerhasználat káros hatásaira vonatkozó ismeretek átadásával kialakítható a fiatalokban a pszichoaktív szerekkel szembeni negatív attitüd. A primer prevenció célja az egészségközpontú szemlélet ki- alakítása. A nyugtatószerek káros használatának megelőzésében a felnőtt korú betegek esetében is központi szerepe van a megfelelő információátadásnak. A hazai állami szakrendelőben megjelenő páciensek közül az első helyen az orvostól való információszerzés, míg második helyen - 10\%-kal lemaradva - az internetes tájékozódás áll [9]. Ez alapján a felnőtt korú lakosság körében továbbra is az orvosok azok, akik a leghatékonyabb prevenciós tevékenységet tudják kifejteni. Fontos ugyanakkor az interneten a nyugtatókkal kapcsolatos korrekt, a hosszabb távú gyógyszerszedés veszélyeit is hangsúlyozó tájékoztatás is.

\section{A vizsgálat limitációi}

A személyes interjú csak részlegesen biztosította a vizsgálat anonimitását, és bár a kérdések értelmezésében segítséget adhatott a vizsgálatban részt vevőknek, ami a félreértés lehetőségét csökkentette, a vizsgálatvezető személye befolyásolhatta az interjúalanyok válaszait. A kis mintaszám miatt további vizsgálatokra lenne szükség ahhoz, hogy a demográfiai adatokat illetően megalapozottabb következtetéseket tudjunk levonni a gyógyszerfüggőségre vonatkozóan. A kérdésekre adott válaszok validitásának, valamint a kérdőív hitelességének és megbízhatóságának igazolása további vizsgálatokat igényel.

\section{Következtetések}

Az eredmények a gyógyszerfüggőség gyakoriságára hívják fel a figyelmet az addiktológiai és a pszichiátriai betegek között, jelezve, hogy sürgős lépések szükségesek a probléma visszaszorítása érdekében.

Anyagi támogatás: A közlemény megírása, illetve a kapcsolódó kutatómunka anyagi támogatásban nem részesült.

Szerzői munkamegosztás: A vizsgálathoz használt kérdőív összeállítását és a vizsgálat megtervezését M. B. és G. G. végezte. Az adatgyújtés T. V. munkája. Az adatok statisztikai feldolgozását G. G. végezte. A kézirat első változatát T. V. írta, majd G. G. és M. B. javította. A cikk végleges változatát mindhárom szerző elolvasta és jóváhagyta.

Érdekeltségek: A szerzőknek nincsenek a kéziratban ismertetett kutatással kapcsolatban érdekeltségeik.

\section{Köszönetnyilvánítás}

A szerzők köszönetüket fejezik ki a vizsgálati kérdőívet kitöltő betegeknek. Ugyancsak köszönik az angol nyelvű összefoglalás véleményezésében nyújtott segítséget Prof. Ungvári Gábornak. 


\section{Irodalom}

[1] Bayer I. History of drugs. The history of drugs from ancient times till nowadays. [A drogok történelme. A kábítószerek története az ókortól napjainkig.] Aranyhal Könyvkiadó, Budapest, 2000. [Hungarian]

[2] ESPAD. Reports \& Documents. Available from: http://www. espad.org/reports-documents [accessed: January 3, 2019].

[3] Paksi B, Arnold P, Kun B, et al. Associations of different drug user behaviours in the Hungarian adult population. [A különböző szerhasználó magatartások kapcsolódása a magyarországi felnőtt népesség körében.] Psychiatr Hung. 2011; 26: 258-266. [Hungarian]

[4] Tasks of the National Health Insurance Fund of Hungary. Drug flow data - 2017. [Nemzeti Egészségbiztosítási Alapkezelő. Gyógyszerforgalmi adatok - 2017.] Available from: http:// neak.gov.hu/felso_menu/szakmai_oldalak/publikus_forgalmi_ adatok/gyogyszer_forgalmi_adatok/forg_adat_arch_2007.html [accessed: September 2, 2018]. [Hungarian]

[5] Hungarian National Focal Point. Annual reports. [Nemzeti Drog Fókuszpont. Éves jelentések.] Available from: http:// drogfokuszpont.hu/eves-jelentesek [accessed: September 22, 2018]. [Hungarian]

[6] Ashton H. Benzodiazepine withdrawal: outcome in 50 patients. Br J Addict. 1987; 82: 665-671.

[7] Paksi B. Prevalence of sleeping and sedation. In: Drugs and adults. [Altató- és nyugtatófogyasztás elterjedtsége. In: Drogok és felnőttek.] L'Harmattan, Budapest, 2003; pp. 74-75. [Hungarian]

[8] Decree No. 80/2013 (X. 16.) of the Hungarian National Assembly on the anti-drug strategy 2013-2020. [80/2013. (X. 16.) Országgyúlési határozat a Nemzeti Drogellenes Stratégiáról 2013-2020.] Available from: https://mkogy.jogtar. hu/?page $=$ show\&docid=al3h0080.OGY [accessed: February 15, 2019]. [Hungarian]

[9] Molnár R, Sági Z, Fejes Zs, et al. Ways, how outpatients acquire medical information. [Egészségügyi információszerzés módjai a szakrendelésen megjelent betegpopuláció körében.] Metszetek 2017; 6: 124-138. [Hungarian]

(Gazdag Gábor dr., Budapest, Köves út 1., 1204 e-mail: gazdag@lamb.hu)

\section{"Occasio aegre offertur, facile amittitur." (Nehezen jön az alkalom, s könnyen szalasztjuk el.)}

A cikk a Creative Commons Attribution 4.0 International License (https://creativecommons.org/licenses/by/4.0/) feltételei szerint publikált Open Access közlemény, melynek szellemében a cikk bármilyen médiumban szabadon felhasználható, megosztható és újraközölhetö, feltéve, hogy az eredeti szerző és a közlés helye, illetve a CC License linkje és az esetlegesen végrehajtott módosítások feltüntetésre kerülnek. (SID_1) 